\title{
Influence of bioturbation on denitrification activity in Mediterranean coastal sediments: an in situ experimental approach
}

\author{
Franck Gilbert*, Georges Stora, Patricia Bonin \\ Laboratoire d'Océanographie et de Biogéochimie, Centre d'Océanologie de Marseille (OSU), \\ Université de la Méditerranée, UMR CNRS 6535, Campus de Luminy, Case 901, F-13288 Marseille Cedex 9, France
}

\begin{abstract}
An in situ experiment was conducted in the French Mediterranean littoral (Gulf of Fos) from July 1993 to January 1994 using controls without macrofauna or natural sediments. After 1, 4 and $6 \mathrm{mo}$, sediment reworking and denitrification activities (natural and potential rates) were studied. The bacterial processes were stimulated by the bioturbating activity of the autochthonous infauna. The natural and potential denitrification rates were 160 and $280 \%$ higher, respectively, than in the controls. The increase of denitrification, occurring at different depths in the sediment with respect to time, was directly dependent on the macrofaunal activity.
\end{abstract}

KEY WORDS: Bioturbation Denitrification. In situ experiment - Mediterranean Sea

\section{INTRODUCTION}

Because of their activities in the sediment (feeding, burrowing, and bioirrigation), infaunal macro-organisms are known to play a crucial role in microbial activities and exchanges at the sediment-water interface (Aller 1980, Jørgensen \& Revsbech 1985, Hüttel 1990, Binnerup et al. 1992). The effects of bioturbation on the nitrogen cycle and more particularly on denitrification have been extensively examined in in vitro studies (Chatarpaul et al. 1980, Kristensen \& Blackburn 1987, Gilbert et al. 1995j. Results from these studies have provided evidence for the quantitative role of bioturbation in various processes, e.g. enhanced nitrate supply (Kristensen et al. 1991) and stimulated coupling of nitrification-denitrification (Aller et al. 1983, Pelegrí et al. 1994), indicating that different, although mainly monospecific, macrofaunal populations may affect denitrification in coastal sediments. But the question remains whether a high denitrification potential which can be demonstrated in vitro is effective in the natural

•E-mail: gilbert@com.univ-mrs.fr environment. To date, only 1 in situ study carried out in Danish estuarine sediments, showing the in situ stimulation of denitrification by an amphipod population, has provided an answer to this question (Rysgaard et al. 1995)

The aim of our field experiment was to investigate the in situ effects of the activities of the whole of the autochthonous infauna on denitrification in Mediterranean coastal sediments.

\section{MATERIALS AND METHODS}

Experimental site. The site chosen was in the shallow water of Carteau cove situated on the western side of the Gulf of Fos (Fig. 1). Experiments were carried out at $5 \mathrm{~m}$ depth. The sediment is rich in organic matter (organic content ranging from 5.00 to $7.32 \%$ ), and is classified as 'muddy sand sediment' (25 to $50 \%$ grains less than $63 \mu \mathrm{m}$ ), and is occupied by a macrofaunal assemblage characteristic of muddy sand in sheltered areas (Pérès 1982). During our experiment, polychaetes dominated the benthic macrofauna $(70 \%)$ and crustaceans were the second most dominant group 


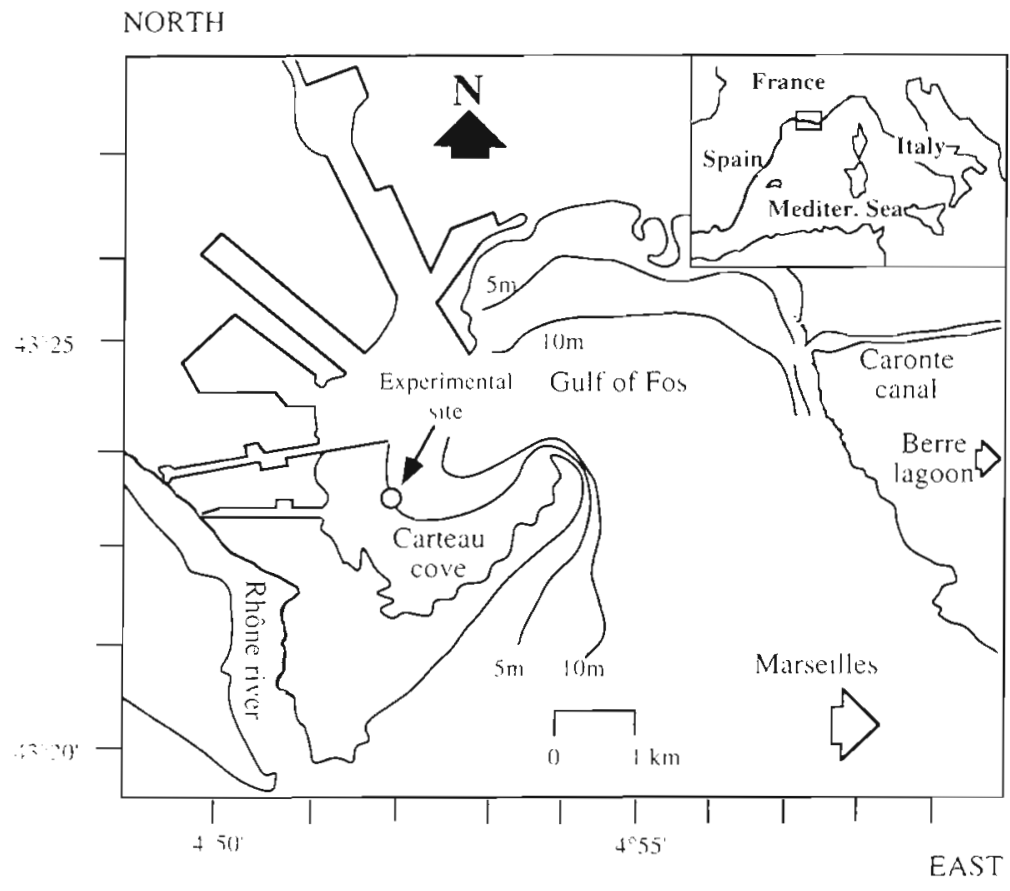

Fig. 1. Experimental site in the Gulf of Fos (Mediterranean Sea, France) standardize the experimental conditions, 6 sediment cakes without luminophores were added to the remaining 6 cores.

Defaunation of control sediment. Control sediments were defaunated by an exclusion/transplant process: 6 sediment cores were taken by divers with experimental core tubes and transported to the laboratory in the following hour. In the Iaboratory, defaunation of sediments was achieved by sealing cores and stripping off $\mathrm{O}_{2}$ present in the overlying water by a stream of $\mathrm{N}_{2}$ (' $\mathrm{N}_{2}$ method'; Kristensen et al. 1991). After $24 \mathrm{~h}$ at $24^{\circ} \mathrm{C}$, dead and dying infauna that had climbed up to the sediment surface were collected and the sediment surface was gently homogenized to plug the burrow openings. The surface water was then aerated to restore oxic conditions after defaunation.
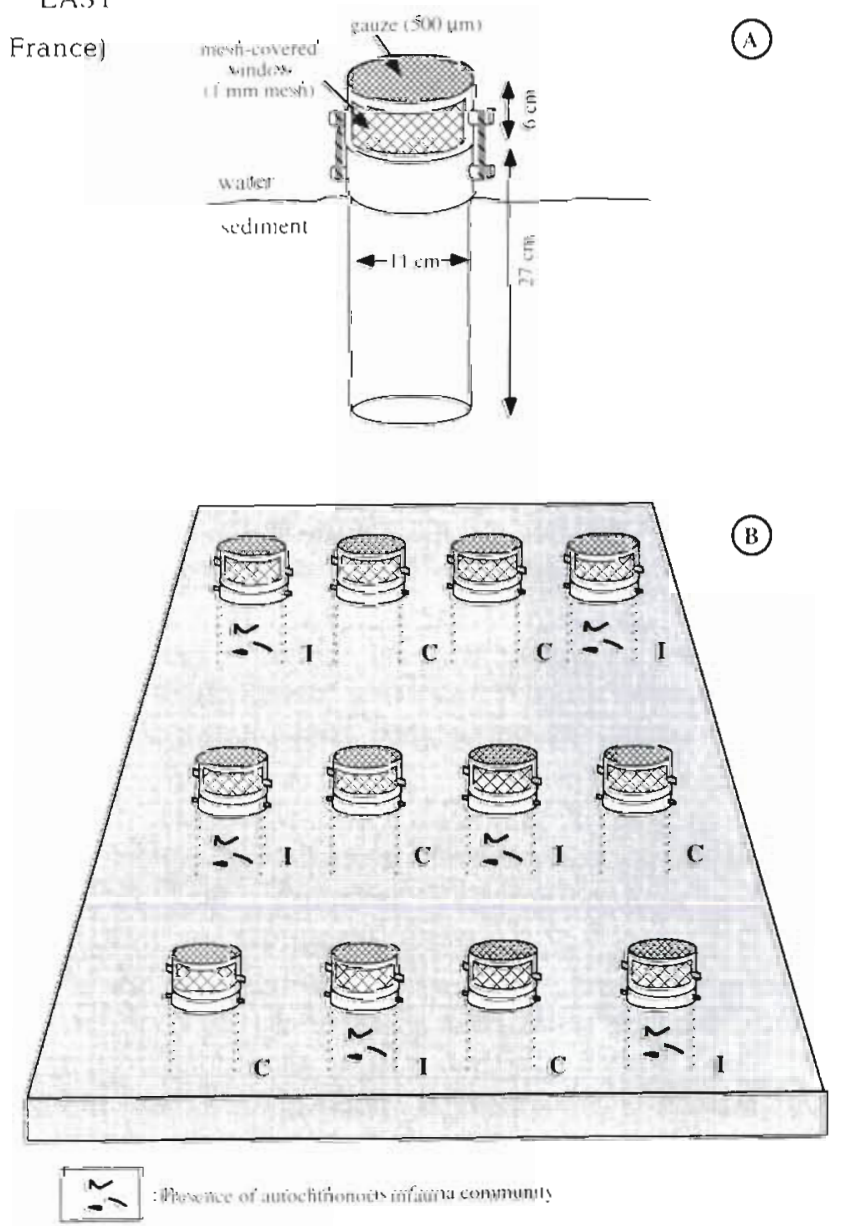

$(25 \%)$. The other faunistic groups present were molluscs and echinoderms $(5 \%)$. The total macrofaunal benthic density varied from 2580 to 3160 ind. $\mathrm{m}^{-2}$. More than $80 \%$ of the organisms were located in the upper $4 \mathrm{~cm}$ of sediment (Gilbert 1994).

Experimental procedure. Twelve core tubes divided into 2 groups were inserted into the sediment (Fig. 2B): $6 \mathrm{C}$-core tubes (control sediment), containing macrofauna defaunated sediment, and 6 I-core tubes (inhabited sediment), containing natural sediment with autochthonous infauna. The core tubes were made from $27 \mathrm{~cm}$ long sections of $11 \mathrm{~cm}$ diameter PVC tubing (Fig. 2A). Caps were designed to slow down recolonization of the defaunated control sediments by macrofauna, without confining the area overlying the sediment surface. The caps were made from $6 \mathrm{~cm}$ long PVC tubing (diam.: $11 \mathrm{~cm}$ ). The tops of the caps were closed with gauze $(500 \mu \mathrm{m})$, and the sides contained 2 mesh-covered windows $(11.2 \mathrm{~cm}$ long, $3.8 \mathrm{~cm}$ high, $1 \mathrm{~mm}$ mesh) to allow water circulation in the cores. To ensure standard experimental conditions, all the cores (defaunated and inhabited) were equipped with caps.

Analysis of sediment mixing. Mixing of the sediment was assessed by the luminophore tracer technique (Gerino 1990). Two size fractions of luminophores, 40 to $60 \mu \mathrm{m}$ diameter and 150 to $200 \mu \mathrm{m}$ diameter, were used. A mixture of the 2 luminophore fractions $11 \mathrm{~g}$ per fraction) was added to the surface of 6 cores ( 3 defaunated and 3 inhabited) in the form of a frozen 'sediment cake' (diam.: $10 \mathrm{~cm}, 1 \mathrm{~cm}$ thick; Gilbert et al. 1994). In order to
Fig. 2. (A) Experimental core design and (B) disposition of the different cores into the sediment $(B)$. C: control defaunated cores; $I$ : inhabited cores 
The influence of this defaunation procedure on the microbial community is assumed to be insignificant (Kristensen et al. 1991).

Implantation of cores. After laboratory treatment, the defaunated sediment cores were transported back to the experimental site and transplanted. At the same time, 6 other core tubes (corresponding to the 'l-core tubes') were simply embedded in the sediment. Then the various additional cakes and the caps were added to the respective cores. The cores were checked weekly at the experimental site by divers. Dirty caps were brushed or replaced by new ones. During each sampling (after 1, 4, and $6 \mathrm{mo}$ ), 4 sediment cores were transported to the laboratory and the analyses were performed on $2 \mathrm{~cm}$ thick sediment segments from the top down to $10 \mathrm{~cm}$

Biological and chemical analyses. Natural and potential denitrification rates were assessed using the acetylene-blockage method (Raymond et al. 1992, Gilbert et al. 1997). Subsamples (4 ml) from each segment were transferred into $13 \mathrm{ml}$ tubes containing $4 \mathrm{ml}$ of natural sea water supplemented either with only chloramphenicol $\left(1 \mathrm{~g} \mathrm{l}^{-1}\right)$ to prevent bacterial growth during incubation (for the natural activity) or with chloramphenicol, glucose $\left(1 \mathrm{~g} \mathrm{l}^{-1}\right)$ and $\mathrm{KNO}_{3}(1 \mathrm{mM})$ (for the potential activity, according to Tiedje et al. 1989). The tubes were sealed with rubber stoppers and anaerobic conditions obtained by flushing $\mathrm{N}_{2}$ through the tube for $2 \mathrm{~min}$. Acetylene, which inhibits the reduction of $\mathrm{N}_{2} \mathrm{O}$ to $\mathrm{N}_{2}$ (Balderston et al. 1976), was injected in the gas phase (final concentration $15 \mathrm{kPa}$ ) and the tubes were vortexed. Samples were incubated in the dark at in situ temperature for 0, 0.5, 1 and $3 \mathrm{~h}$. After incubation each tube was treated with $0.1 \mathrm{ml}$ of $1 \mathrm{M}$ $\mathrm{HgCl}_{2}$ solution, vigorously shaken by hand for $2 \mathrm{~min}$, and then centrifuged at $2000 \mathrm{rpm}(350 \times \mathrm{g})$ for $3 \mathrm{~min}$. Denitrifying activity was considered as the linear initial rate of $\mathrm{N}_{2} \mathrm{O}$ accumulation. After incubation, nitrous oxide was measured in the headspace and in sea water. A subsample $(2.5 \mathrm{ml})$ of gas phase was injected into a $3 \mathrm{ml}$ pre-evacuated tube (Venoject, Terumo, Leuven, Belgium) for later $\mathrm{N}_{2} \mathrm{O}$ analysis. The extraction of $\mathrm{N}_{2} \mathrm{O}$ from the liquid phase was carried out using the procedure of Chan \& Knowles (1979) modified by the multiple equilibrium technique (Mac Aullife 1971). Nitrous oxide in the tubes was determined by gas chromatography (Girdel, series 30) using an electron capture detector. Chromatographic operating conditions were $8 \mathrm{ft}$ length 'Porapak $\mathrm{Q}^{\prime}$ column (mesh $50 / 80$ ), oven temperature $80^{\circ} \mathrm{C}$, injector temperature $180^{\circ} \mathrm{C}$, detector temperature $250^{\circ} \mathrm{C}$. Nitrogen was used as carrier gas at a flow rate of $20 \mathrm{ml} \mathrm{min}^{-1}$ (Bonin et al. 1987).

$N$ compounds (nitrates and nitrites) were measured in the supernatant obtained after centrifugation at
$2000 \times g$ for 10 min. Nitrates were reduced on a Cu-Cd column adapted to Technicon II according to Tréguer \& Le Corre (1975). Nitrite concentrations were determined colorimetrically by the method of Bendschneider \& Robinson (1952).

Luminophore analyses were carried out as described by Gerino (1990). After sectionning, each slice of sediment was dried at $70^{\circ} \mathrm{C}$ for $1 \mathrm{wk}$, carefully mixed to homogenize sediment and luminophores, and sieved through a $500 \mu \mathrm{m}$ mesh. For each segment, 3 subsamples of $0.25 \mathrm{~g}$ were taken. The luminophore counts were then conducted under an ultraviolet light source.

Data analysis. Differences between control and inhabited sediments and the space-time variations of denitrifying activity rates were studied using a 3-way analysis of variance (ANOVA). Bartlett's test was employed to test for homogeneity of variance. Heteroscedastic data were transformed and then evaluated using ANOVA.

\section{RESULTS}

\section{Bioturbation}

After 1 mo, no luminophore burial had occurred in control sediments (C-cores) (Fig. 3). The luminophore losses from the sediment due to the removal of particles into the water column were $53.7 \%$ (C-cores) and $36.8 \%$ (I-cores). The total recovery of luminophores in the deposit layer $(0-2 \mathrm{~cm})$ was $46.3 \%$ (926 mg). In inhabited sediments (I-cores), bioturbation displaced $17.7 \%$ (354 mg) of the luminophores between 2 and $10 \mathrm{~cm}$ depth, while $43.7 \%$ (874 $\mathrm{mg}$ ) remained in the surface layer. In the bioturbated sedimentary column, the number of luminophores decreased with depth. After $4 \mathrm{mo}, 14.7 \%$ (294 $\mathrm{mg})$ of the luminophores were found in the C-cores. They were principally located in the $0-2 \mathrm{~cm}$ layer (Fig. 3). A very small quantity of luminophores ( $66 \mathrm{mg} ; 3.3 \%$ ) was buried down to $6 \mathrm{~cm}$ $(<0.1 \%)$. In I-cores, where $13.0 \%$ (260 mg) were recorded in the surface layer, the number of luminophores distributed between 2 and $8 \mathrm{~cm}$ depth of sediment had increased compared to those found after $1 \mathrm{mo}$ and reached $36.8 \%$ (736 $\mathrm{mg}$ ). The maximum numbers of luminophores were found in the $2-4 \mathrm{~cm}$ layer. After $6 \mathrm{mo}, 5.1 \%$ (102 mg) of luminophores were buried down to $4-6 \mathrm{~cm}$ in C-cores (Fig. 3), whereas $14.1 \%$ (282 $\mathrm{mg}$ ) of luminophores were found down to $10 \mathrm{~cm}$ depth in I-cores. Since the previous samplings, increased losses of luminophores from sediments had occurred in all cores. Only $0.8 \%(16 \mathrm{mg})$ and $4.1 \%$ (82 $\mathrm{mg}$ ) of luminophores were found in the initial deposit layer in C-cores and I-cores, respectively. 

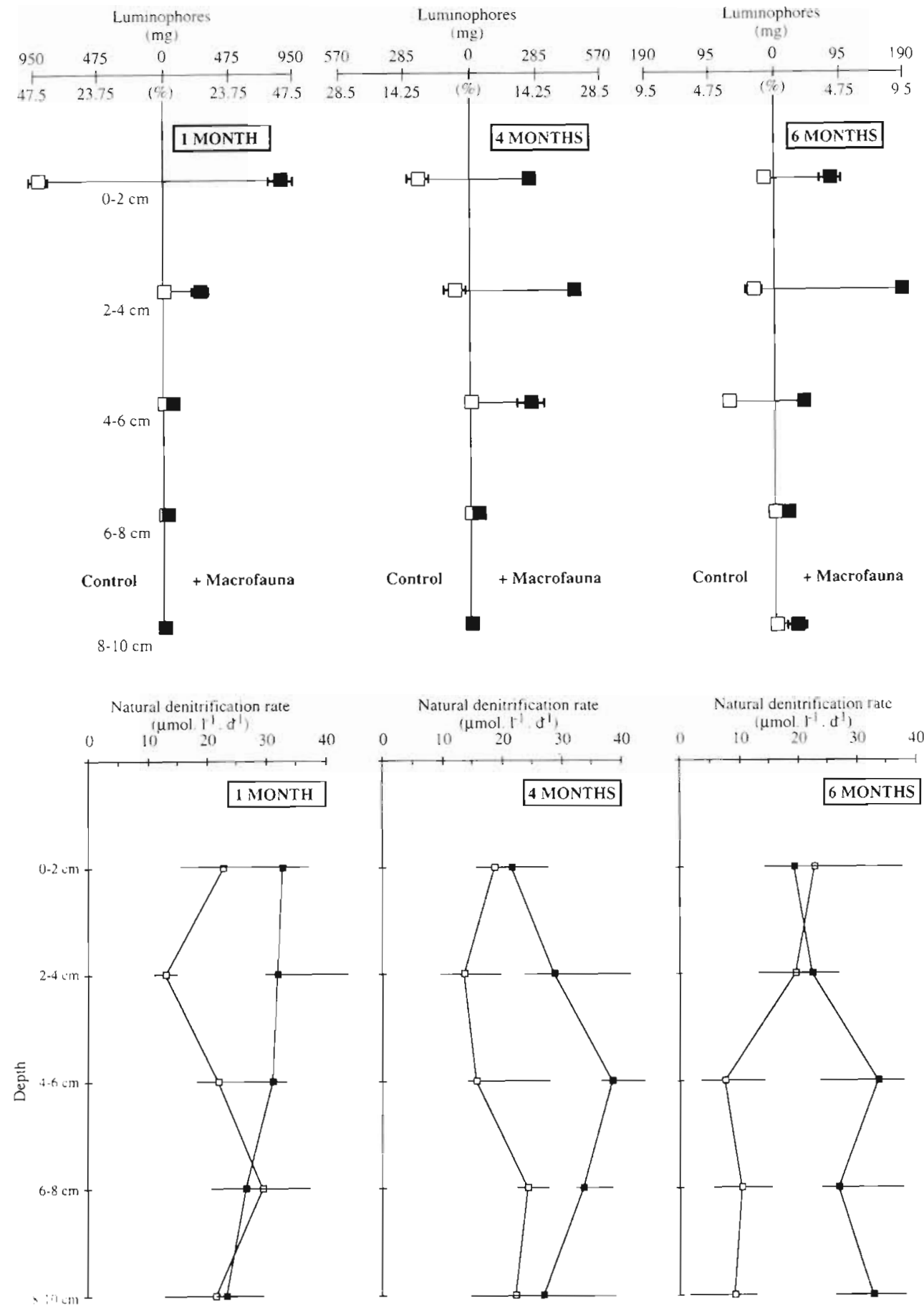

\section{Denitrification}

Natural denitrification. Natural denitrification rates measured in the sediments ranged from 10 to $40 \mu \mathrm{mol}$ $\mathrm{l}^{-1} \mathrm{~d}^{-1}$ (Fig. 4) for $\mathrm{NO}_{3}^{-}$and $\mathrm{NO}_{2}^{-}$concentrations between 0.4 and $4.3 \mu \mathrm{M}$ (Fig. 5) and 0.3 and $4.0 \mu \mathrm{M}$ (Fig. 6), respectively. There was no difference in the nutrient profiles between control and inhabited sediments.
Fig. 3. Vertical distribution with time of luminophores in the sedimentary column for the different sediments, expressed in both milligrams and percentage of recovery from the initial deposit. Standard errors of the means are shown $(\mathrm{n}=3)$. (口) Control

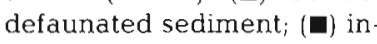
habited sediment

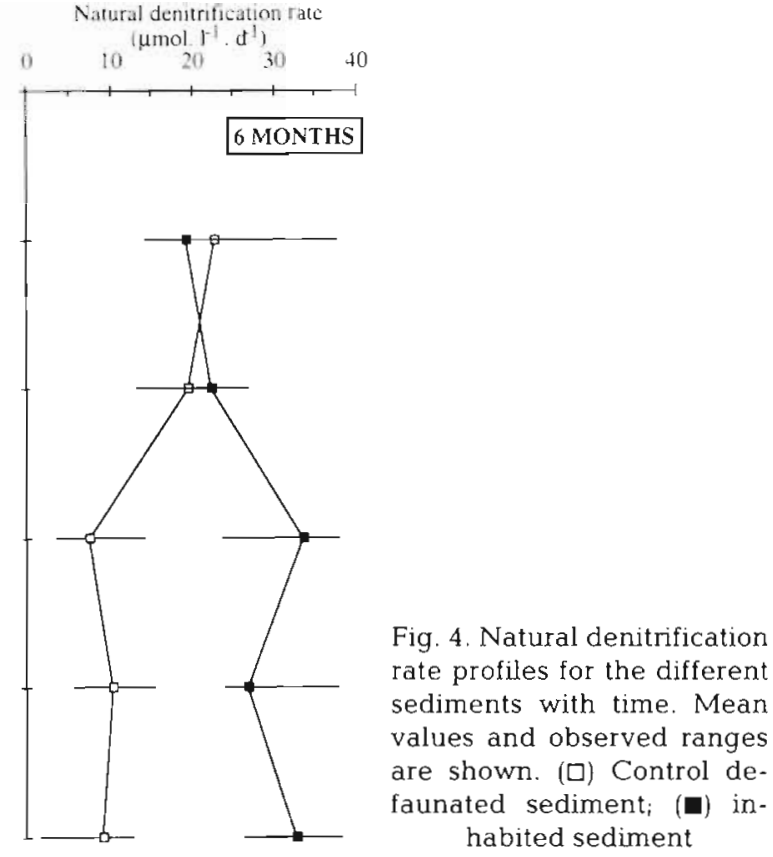

After $1 \mathrm{mo}$, denitrification was higher in presence of infauna down to $6 \mathrm{~cm}$ depth. Below this depth, control and inhabited sediments had the same denitrification rates. After $4 \mathrm{mo}$, the increase in the natural denitrification rate of the inhabited sediments was found throughout the sedimentary column. After $6 \mathrm{mo}$, in contrast, the increase in denitrification in the inhabited sediment occurred at greater depth $(4-10 \mathrm{~cm})$. The denitrification rates for the 2 types of sediment (control 
Fig. 5. Nitrate concentration profiles for the different sediments with time. ( $\square$ ) Control defaunated sediment; ( $(\square)$ inhabited sediment
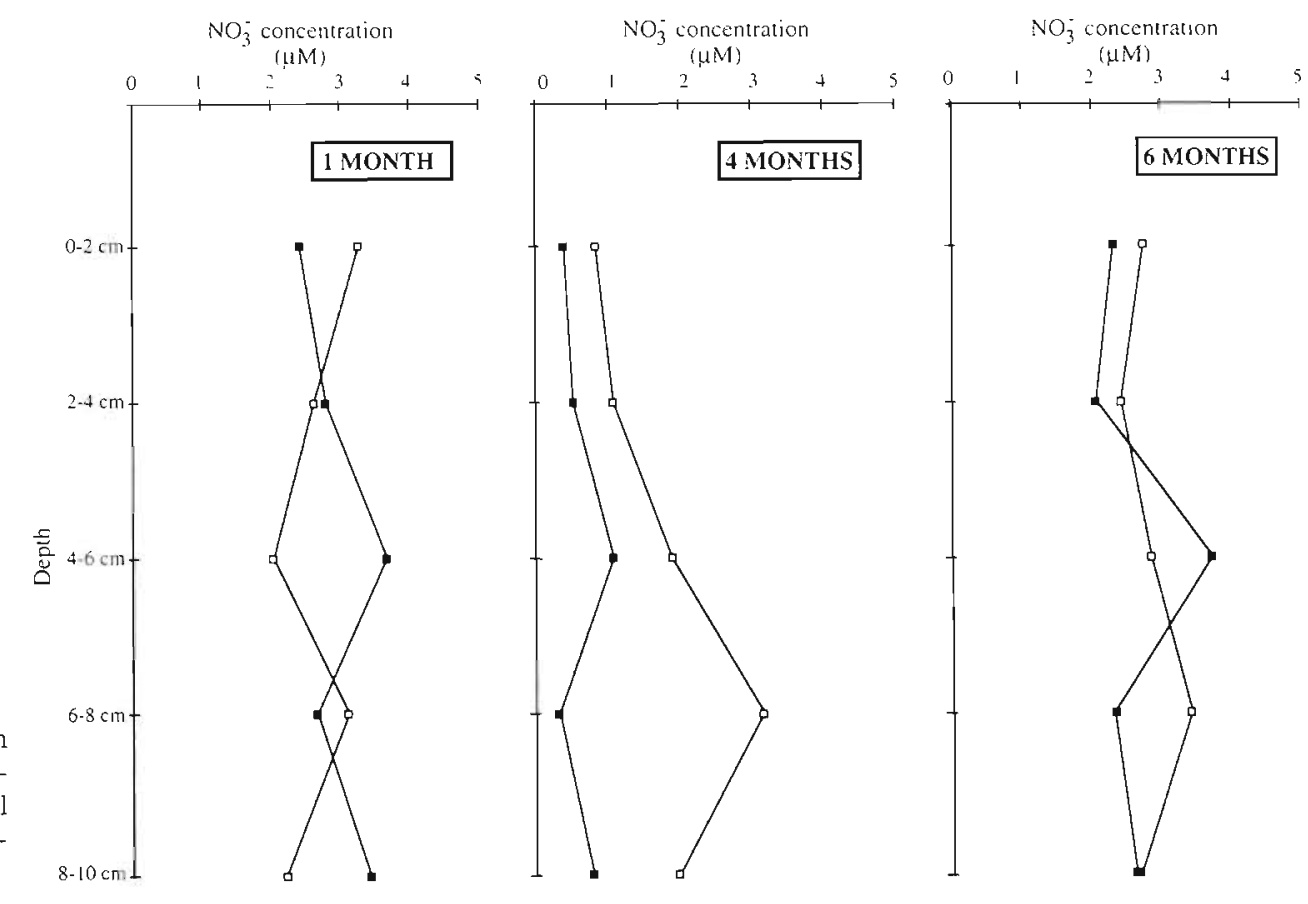

Fig. 6. Nitrite concentration profiles for the different sediments with time. (a) Control defaunated sediment; ( $\mathbf{\square}$ ) inhabited sediment
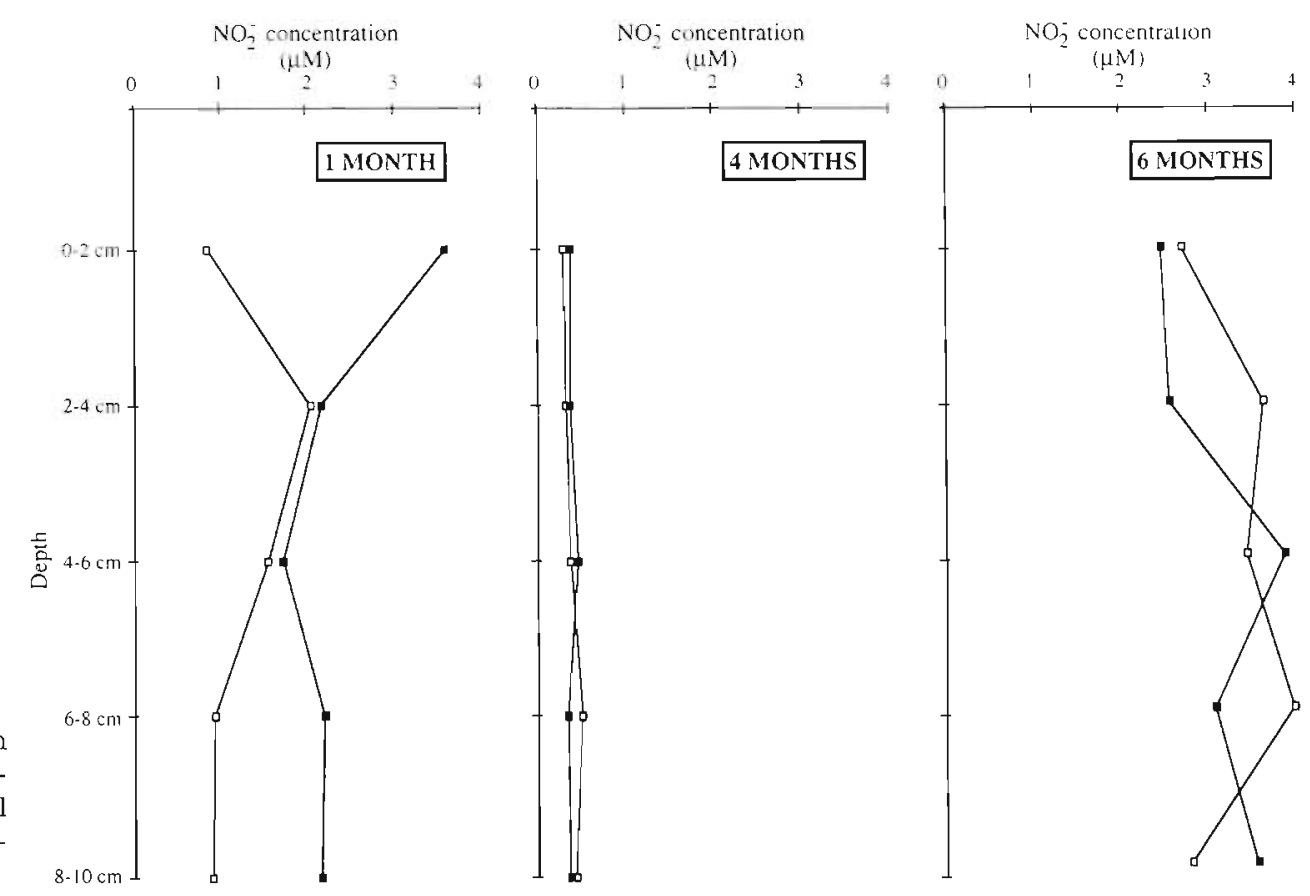

and inhabited) were within the same range near the sediment surface.

Potential denitrification. After $1 \mathrm{mo}$, potential denitrification was higher in presence of infauna down to $4 \mathrm{~cm}$ depth (Fig. 7). Below this depth, control (C-cores) and inhabited (I-cores) sediments presented the same order of potential denitrifying activities, averaging $70 \mathrm{\mu mol} \mathrm{l}^{-1} \mathrm{~d}^{-1}$. After $4 \mathrm{mo}$, the increase of potential

denitrification in the inhabited sediments had spread throughout the sedimentary column. In the first $6 \mathrm{~cm}$, potential denitrification was about 2 -fold higher than 3 mo before. After 6 mo, a general decrease in the potential denitrification was found in inhabited sediments. However, denitrification rate was always higher compared to control sediment rate in the first $6 \mathrm{~cm}$. 

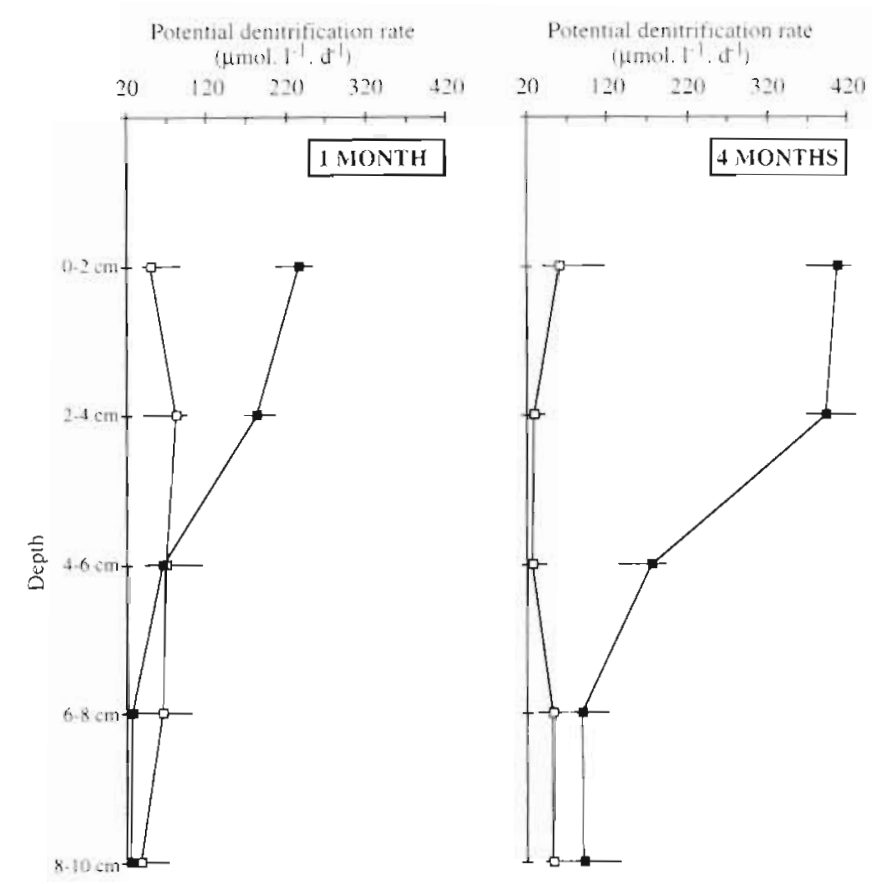

\section{DISCUSSION AND CONCLUSIONS}

Although the macrobenthic communities present in sediments may have been determined (major species: Clymene oerstedi, Loripes lacteus, Microdeutopus anomalus and Venerupis aurea; Gilbert 1994), in the course of this study, only the consequences of the macrobenthic activity in the sedimentary column are presented and discussed.

The caps were used to limit recolonization in defaunated sediments (C-cores). This physical barrier was chosen instead of chemical contamination (e.g. by tetraethyl lead as used by Gerino 1990) which may perturb the microbial activity rates in sediments. In order to detect and quantify the presence and activity of infauna in cores, we have followed the fate of luminophores deposited at the sediment surface. It appeared that, after $4 \mathrm{mo}$, no sediment mixing had occurred in control sediments (C-cores). On the other hand, after $6 \mathrm{mo}$, the burial of luminophores was found down to $6 \mathrm{~cm}$ depth, demonstrating a partial recolonization of controls.

Based on the luminophore results, the sedimentary column can be described as a '2 layer' system (Gerino et al. 1993): (1) a subsurface layer ('reworked layer') where the occurrence of reworking activity and macrofauna is highest (between the sediment surface and $4 \mathrm{~cm}$ depth for this experiment; Gilbert 1994); the sediment also being well bio-irrigated in this active layer. Below the active layer, the 'bioturbated layer' (2) extends further down to the maximum depth of the burrows.

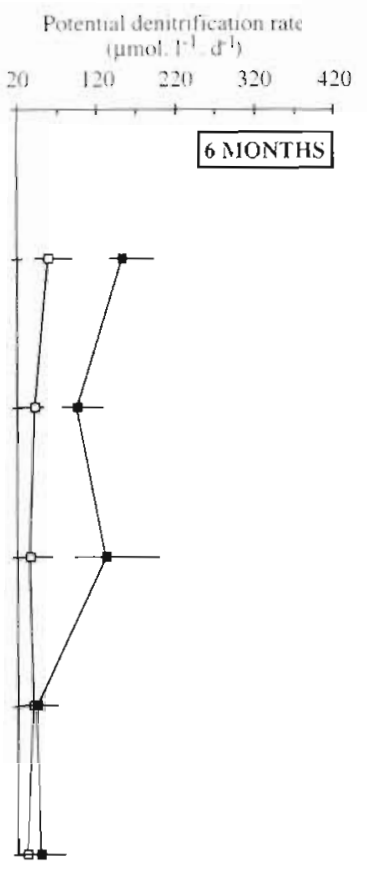

Fig. 7. Potential denitrification rate profiles for the different sediments with time. Mean values and observed ranges are shown. (口) Control defaunated sediment;

(घ) inhabited sediment
In order to find evidence of the overall effects of bioturbation on denitrification, 3-way ANOVAs, taking into account the type of sediment (control or inhabited sediment), the biological layer and the time, were used to analyse the denitrification activities.

A 3-way ANOVA carried out on natural denitrifying activity data showed no significant seasonal or spatial variability in denitrification rate. On the other hand, a very significant $(\mathrm{p}<0.001, \mathrm{df}=1, F=42.39$ ) increase of denitrification was found in inhabited sediment (28.6 \pm $1.4 \mu \mathrm{mol} \mathrm{l}^{-1} \mathrm{~d}^{-1}$; mean $\pm \mathrm{SE}$ ) compared to controls $\left(18.1 \pm 1.6 \mu \mathrm{mol} \mathrm{l}^{-1} \mathrm{~d}^{-1}\right)$. While denitrification was enhanced $160 \%$ by bioturbation, the 'small-scale geometry' (each $2 \mathrm{~cm}$ sediment) of this stimulation in the sedimentary column was variable with time. At each sampling time, the stimulation of denitrification was located in the depth layers were the infauna was most active. In the first phase ( $1 \mathrm{mo})$, the macrofaunal activity occurred in the sediment down to $6 \mathrm{~cm}$ depth. Later ( $4 \mathrm{mo})$, the sediment reworking area was extended by infauna to the whole sedimentary column studied (down to $10 \mathrm{~cm}$ depth). After $6 \mathrm{mo}$, the infaunal activity in I-cores still occurred in the first $10 \mathrm{~cm}$ of the sediment. However, at this stage, the infauna had recolonized the upper layers of the initially defaunated sediment (C-core). A difference of macrofaunal activity and denitrification between the inhabited (I-core) and control (C-core) was at this stage only found in the deeper layers. As reported in other studies (Sørensen 1978, Law et al. 1991), the presence of burrowing activity of benthic macrofauna was reflected by high denitrification rates in the deeper layers of the sediment. 
The 3-way ANOVA on potential denitrification showed significant interactions between the sediment treatment (animals or no animals) and time ( $\mathrm{p}<0.001$ ), and between the sediment treatment and the sediment layer $(\mathrm{p}<0.001)$. In control sediments (C-cores), potential denitrification was stable both with time (Fig. 8A) and as a function of the sediment layer (Fig. 8B). On the other hand, in inhabited sediments (I-cores), enhanced potential denitrification was demonstrated throughout the duration of the experiment, with increasing rates between 1 and 4 mo and a subsequent drop after 6 mo (Fig. 8A). Moreover, potential denitrification was higher in the 'reworked layer' than in the 'bioturbated layer' (Fig. 8B), the potential denitrification being from 177 to $529 \%$ higher in inhabited than in control sediments $(p<0.001)$. The 'small-scale geometry' pattern of macrofaunal activity and the associated stimulation of potential rate was less evident than that found with natural denitrification. Indeed, the potential denitrification rate reflects the state of the microbial denitrifying population, i.e. the enzyme content of the sediment, but not the actual rate (Tiedje et al. 1982).

In the natural sediments, different events depending on both the activity of macrofauna and its intensity operate in sediments and play a role in the denitrification. In the presence of infauna, sediment reworking and bioirrigation (into the burrows) increase the sediment porosity and the solute exchanges between the sediment and the overlying water. Because of the enhanced oxygen penetration, the oxidized surface layer of the sediment spreads more deeply, which favors nitrification. The nitrate exchanges are also increased by sediment reworking. The macrofauna therefore stimulates denitrification by providing more nitrate for bacteria from 2 sources: the overlying water and nitrification within the sediment. In addition, the presence of oxic (oxygen pocket in the reduced sediment) and anoxic micro-environments (fecal pellets deposited in the oxidized layer) strengthens the proximity and exchanges between nitrification and denitrification.

In our study, we can envisage the major mechanisms implicated in the stimulation of denitrification by the macrobenthos as a function of the dominant bioturbation processes in each 'biological layer'. In the 'reworked layer', the presence of a high sediment reworking activity may have preferentially induced the formation of micro-environments. On the other hand, in the 'bioturbation layer', the bioirrigation associated with the burrows may have resulted in the stimulation of denitrification by enhancing the exchanges of solutes between the water and the sediment. However, it appears too that there was no evidence of an increase of nutrient availability $\left(\mathrm{NO}_{3}{ }^{-}\right.$and
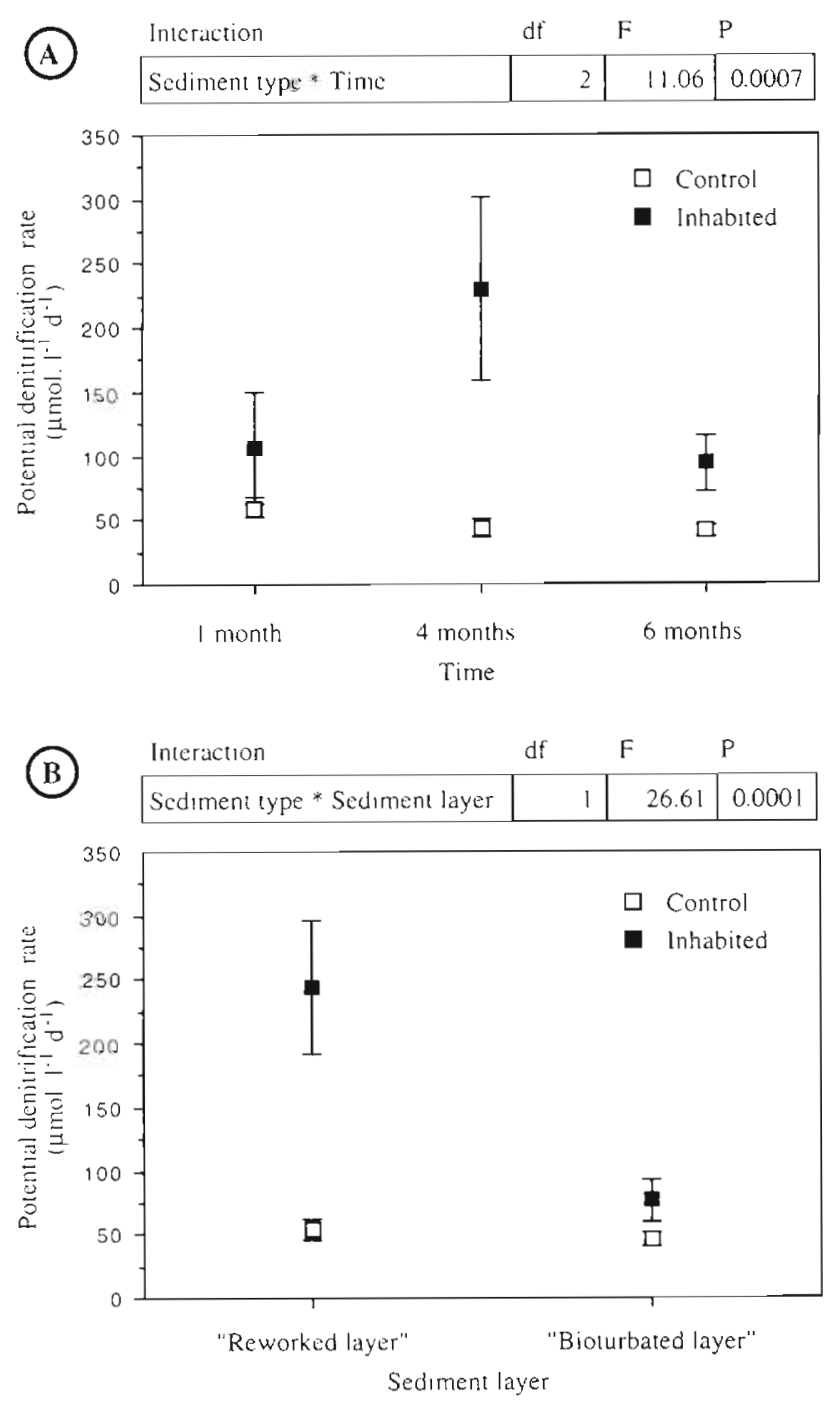

Fig. 8. Potential denitrification rate in the different sediments Standard errors of the mean are shown. ANOVA comparison procedure indicates significant interactions $(p<0.001)$ between (A) the type of sediment (control or inhabited) and time, and (B) the type of sediment and the sediment layer (reworked or bioturbated layer) $(p<0.001)$

$\mathrm{NO}_{2}{ }^{-}$) due to bioturbation. This could be explained by the rapid consumption of nutrients by denitrification (Sayama \& Kurihara 1983, Hüttel 1990) but also by problems relative to the experimental procedure used (the thickness of sediment slice attenuating the nutrient profilesj.

Our experiment was carried out in a natural sediment occupied by an assemblage characteristic of muddy sand in sheltered areas. It appears that the in situ increases of the denitrification rates induced by the whole macrobenthic community are within the same range as those found in previous monospecific laboratory and field experiments (Table 1). From their 
Table 1. Denitrification stimulation rates induced by the benthic macrofauna in estuarine and coastal sediments. MSSA assemblage: macrofaunal assemblage in muddy sand in sheltered areas (Pérès 1982)

\begin{tabular}{|c|c|c|c|c|}
\hline $\begin{array}{l}\text { Experimental } \\
\text { conditions }\end{array}$ & $\begin{array}{l}\text { Bioturbating } \\
\text { organism }\end{array}$ & $\begin{array}{l}\text { Density } \\
\text { (ind. } \mathrm{m}^{-2} \text { ) }\end{array}$ & $\begin{array}{c}\text { Denitrification } \\
\text { stimulation rate }(\%)\end{array}$ & Source \\
\hline $\begin{array}{l}\text { Laboratory } \\
\text { Columns }\end{array}$ & $\begin{array}{l}\text { Limnodrilus hoffmeisteri } \\
\text { and Tubifex tubifex }(1 / 1)\end{array}$ & 12000 & 180 & Chatarpaul et al. (1980) \\
\hline Aquaria & Nereis virens & 2000 & 171 & Henriksen et al. (1980) \\
\hline Aquaria & Corophium volutator & 6000 & 161 & Henriksen et al. $(1980\}$ \\
\hline Aquaria & Neanthes japonica & 1000 & 300 & Sayama \& Kurihara (1983) \\
\hline Cores & Nereis virens & 1807 & 240 & Kristensen \& Blackburn $(1987$ \\
\hline V-cores & Nereis virens & 875 & 300 & Kristensen et al. (1991) \\
\hline Microcosms & Corophium volutator & 19800 & 300 to 500 & Pelegri et al. (1994) \\
\hline Cores & Nereis diversicolor & 1433 & 114 & Gilbert et al. (1995) \\
\hline $\begin{array}{l}\text { Field } \\
\text { Cores }\end{array}$ & $\begin{array}{l}\text { Amphipods } \\
\text { (Corophium spp.) }\end{array}$ & $\begin{array}{l}3000 \\
9000\end{array}$ & $\begin{array}{l}400 \\
950\end{array}$ & Rysgaard et al. (1995) \\
\hline Cores & MSSA assemblage & 3160 & 160 to 529 & Present study \\
\hline
\end{tabular}

in situ experiment, Rysgaard et al. (1995) concluded that the stimulatory effect of infauna during summer is of minor importance with regard to the annual denitrification budget due to low $\mathrm{NO}_{3}{ }^{-}$concentrations and nitrification potentials, although the benthic infauna density generally is highest in summer. Even so, our field study, based on the comparison between control defaunated and inhabited sediments, indicates that in presence of bioturbating macrofauna the denitrification rate is always higher than that recorded in uninhabited sediment.

We conclude that bioturbation by benthic macrofauna significantly stimulates in situ sediment denitrification and that this stimulation of denitrification, which is associated with the sediment layer where the infauna is most active, can occur at different depths in the sediment.

Acknowledgements. This work was carried out as part of the programme 'GDR HYCAR no. 1123: Cycles biogéochimiques des hydrocarbures naturels et anthropiques en milieu marin' and was supported by the Centre National de la Recherche Scientifique (CNRS), the Universities and Elf Aquitaine

\section{LITERATURE CITED}

Aller RC (1980) Quantifying solute distributions in the bioturbated zone of marine sediments by defining an average microenvironment. Geochim Cosmochim Acta 44: $1955-1965$

Aller RC, Yingst JY, UIlman WJ (1983) Comparative biogeochemistry of water in interdidal Onuphis (Polychaeta) and Upogebia (Crustacea) burrows: temporal patterns and causes. J Mar Res 41:571-604

Balderston WL, Sherr B, Payne WJ (1976) Blockage by acetylene of nitrous oxide production in $P_{\text {seudomonas perfec- }}$ tomarinus. Appl Environ Microbiol 81:504-508

Bendschneider K, Robinson RJ (1952) A new spectrophoto- metric method for the determination of nitrite in sea water. J Mar Res 11:87-96

Binnerup $S J$, Jensen $K$, Revsbech $N P$, Hjorth Jensen $M$, Sørensen J (1992) Denitrification, dissimilatory reduction of nitrate to ammonium, and nitrification in a bioturbated estuarine sediment as measured with ${ }^{15} \mathrm{~N}$ and microsensor techniques. Appl Environ Microbiol 58:303-313

Bonin P, Gilewicz M, Bertrand JC (1987) Denitrification by a marine bacterium Pseudomonas nautica Strain 617. Annls Inst Pasteur/Microbiol 138:371-383

Chan YK, Knowles R (1979) Measurement of denitrification in two freshwater sediments by an in situ acetylene inhibition method. Appl Environ Microbiol 37:1067-1072

Chatarpaul L, Robinson JB, Kausmik NR (1980) Effects of tubificid worms on denitrification and nitrification in stream sediment. Can J Fish Aquat Sci 37:656-663

Gerino $M$ (1990) The effects of bioturbation on particle redistribution in Mediterranean coastal sediment. Preliminary results. Hydrobiologia 207:251-258

Gerino M, Stora G, Weber O (1993) Potentialité de bioturbation dans le canyon du Cap Ferret: macrofaune et structures de bioturbation. Actes III Colloq Int Gasc 265-269

Gilbert F (1994) Influence de la bioturbation sur l'activité dénitrifiante dans des sédiments marins côtiers. Effet d'un apport exogène de matière organique: les hydrocarbures. Thèse de l'Université d'Aix-Marseille II, ANRT-Grenoble: 94/AIX2/2053

Gilbert F, Bonin P, Stora G (1995) Effect of bioturbation on denitrification in a marine sediment from the West Mediterranean littoral. Hydrobiologia 304:49-58

Gilbert F, Rivet L, Bertrand JC (1994) The fate of petroleum hydrocarbons in marine sediments: influence of the burrowing polychaete Nereis diversicolor. Chemosphere 29 : $1-12$

Gilbert F, Souchu P, Bianchi M, Bonin P (1997) Influence of shell-farming activities on nitrification, nitrate reduction to ammonium and denitrification at the water-sediment interface of the Thau lagoon. Mar Ecol Prog Ser 151: $143-153$

Henriksen K, Hansen JI, Blackburn TH (1980) The influence of benthic infauna on exchange rates of inorganic nitrogen between sediment and water. Ophelia Suppl 1:249-256

Hüttel M (1990) Influence of the lugworm Arenicola marina 
on porewater nutrient profiles of sand flat sediments. Mar Ecol Prog Ser 62:241-248

Jørgensen $B \varnothing$, Revsbech NP (1985) Diffusive boundary layers and the oxygen uptake of sediments and detritus. Limnol Oceanogr 30:111-122

Kristensen E, Blackburn TH (1987) The fate of organic carbon and nitrogen in experimental marine sediment systems: influence of bioturbation and anoxia. J Mar Res 45:231-257

Kristensen E, Hjorth Jensen M, Aller RC (1991) Direct measurement of dissolved inorganic nitrogen exchange and denitrification in individual polychaete (Nereis virens) burrows. J Mar Res 49:355-377

Law CS, Rees AP, Owens NJP (1991) Temporal variation of denitrification in estuarine sediments. Estuar Coast Shelf Sci 33:37-56

Mac Aullife C (1971) GC determination of solutes by multiple phase equilibration. Chem Tech 1:46-51

Pelegrí SP, Nielsen LP, Blackburn TH (1994) Denitrification in estuarine sediment stimulated by the irrigation activity of the amphipod Corophium volutator. Mar Ecol Prog Ser $105: 285-290$

Pérès JM (1982) Major benthic assemblages. Mar Ecol 5: $373-522$

Raymond N, Bonin P, Bertrand JC (1992) Comparison

Editorial responsibility: Otto Kinne (Editor),

Oldendorf/Luhe, Germany of methods for measuring denitrifying activity in marine sediments from the Western Mediterranean coast. Oceanol Acta 15:137--143

Rysgaard S, Christensen PB, Nielsen LP (1995) Seasonal variation in nitrification and denitrification in estuarine sediment colonized by benthic microalgae and bioturbating infauna. Mar Ecol Prog Ser 126:111-121

Sayama M, Kurihara Y (1983) Relationship between burrowing activity of the polychaetous annelid, Neanthes japonica (Izuka) and nitrification-denitrification processes in the sediments. J Exp Mar Biol Ecol 72:233-241

Sørensen J (1978) Occurrence of nitric and nitrous oxides in a coastal marine sediment. Appl Environ Microbiol 36: $809-813$

Tiedje JM, Sexstone AJ, Myrold DD, Robinson JA (1982) Denitrification: ecological niches, competition and survival. Antonie Leeuwenhoek 48:569-583

Tiedje JM, Sinkins S, Groffman PM (1989) Perspectives on measurement of denitrification in the fields including recommended protocols for acetylene based methods. Plant Soil 115:261-284

Tréguer P, Le Corre P (1975) Manuel d'analyse des sels nutritifs dans l'eau de mer. Laboratoire d'Océanologie chimique, Université de Bretagne Occidentale, Brest

Submitted: April 29, 1997; Accepted: December 10, 1997

Proofs received from author(s): February 6, 1998 